Int. J. Dev. Biol. 52: 377-381 (2008)

doi: $10.1387 / \mathrm{ijdb} .072389 \mathrm{~ns}$

\title{
Expression of zinc transporter family genes in Dictyostelium
}

\author{
NOBUYA SUNAGA\#, MERI MONNA, NAO SHIMADA, MAI TSUKAMOTO and TAKEFUMI KAWATA* \\ ${ }^{1}$ Department of Biology, Faculty of Science, Toho University, Funabashi, Chiba, Japan
}

\begin{abstract}
Regulation of the zinc ion concentration is physiologically important to control the activities of a variety of cellular molecules. A BLAST search against a conserved domain of known zinc transporters identified twelve putative zinc transporter family genes in the Dictyostelium genome. Phylogenetic analysis revealed the presence of three zinc transporter subfamilies in Dictyostelium. One subfamily of proteins, consisting of the ZntA-D proteins, has weak homology to the STAT3-inducible LIV-1 protein. In addition, in situ hybridization revealed that the zntA-D genes are expressed in the pstAB cells, this expression being absent in the Dd-STATa null mutant. Thus, Dd-STATa may control stalk cell differentiation through some members of the zinc transporter family genes during Dictyostelium development.
\end{abstract}

KEY WORDS: STAT transcription factor, zinc transporter, cell differentiation, Dictyostelium

The JAK/STAT signaling pathways are induced by cytokines and growth factors and play indispensable roles in controlling the immune system, cell fate determination, and cell proliferation in an evolutionarily conserved manner (Darnell, 1997; O'Shea et al., 2002; Rawlings et al., 2004). Protozoan cellular slime mould, Dictyostelium discoideum, possesses functional homologs of the metazoan STAT genes, Dd-STATa-d (Kawata et al., 1997; Fukuzawa et al., 2001; Zhukovskaya et al., 2004; Gao et al., 2004). The Dd-STATanull strain has defects in both chemotactic cell movements during the aggregation stage and morphogenesis during late development, and the latter defect leads to a failure of culmination (Mohanty et al., 1999). Thus, Dd-STATa is necessary for the entry into culmination that accompanies proper conversion of prestalk cells into stalk cells.

In Dictyostelium, the conversion of isolated prestalk cells into stalk cells in vitrois enhanced by zinc ions in the presence of DIF1, a differentiation-inducing factor (Kubohara and Okamoto, 1994; Kubohara, 1995). This observation indicates that exogenous zinc ions may have an important role in stalk differentiation, although the mechanism of zinc action remains unclear. STAT3 controls EMT (epithelial-mesenchymal transition) through the LIV-1 protein during zebrafish gastrulation (Yamashita etal., 2004). STAT3 is activated in the organizer region and'activates transcription of the LIV-1 gene, which encodes a zinc transporter protein (McClelland et al., 1998). LIV-1 induces nuclear transition of the zinc finger protein Snail, which is a main regulator of EMT and is a transcriptional repressor of the $\mathrm{E}$-cadherin gene encoding a cell adhesion molecule (Batlle et al., 2000; Cano et al., 2000). Because the Dd-STATanull strain lacks an organizer-like activity, if LIV-1-related molecules are present in Dictyostelium, then they could be regulated by Dd-STATa and may have crucial roles during fruiting body formation.

There are two zinc transporter families in eukaryotes, the CDF (Cation Diffusion Family) and the ZIP (Zrt, Irt-like Proteins) family, the latter family includes LZT (LIV-1 subfamily of ZIP zinc Transporters). While CDF is responsible for zinc transport from the cytoplasm to either intracellular organelles or extracellular spaces, the ZIP family is important for transferring zinc from the extracellular space into the cytoplasm (Taylor and Nicholson, 2003; Liuzzi and Cousins, 2004). The ZIP transporter family consists of four subfamilies: I, II, gufA, and LZT (Gaither and Eide, 2001). The LZT subfamily is distinguished from the other ZIP subfamilies by the presence of the HEXPHEXGD motif in the fifth transmembrane region. This motif is less conserved in other zinc transporter proteins (Taylor and Nicholson, 2003).

To identify putative zinc transporters in Dictyostelium, we searched the amino acid sequences of Zrt, Irt, and ZIP proteins (ZIP subfamilies I and II), LIV-1 and KE4 proteins (LZT subfamily), and $\mathrm{ZnT}$ protein (CDF family) against the entire genomic sequence of Dictyostelium by using the BLAST program. The search identified 12 putative zinc transporter family genes in Dictyostelium (Table 1). Phylogenetic analysis showed that these

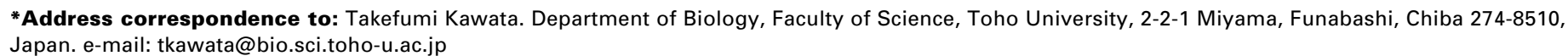

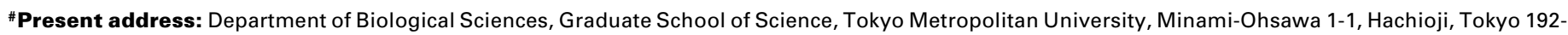
0397, Japan.

Accepted: 7th September 2007. Published online: 26th December 2007. 
A

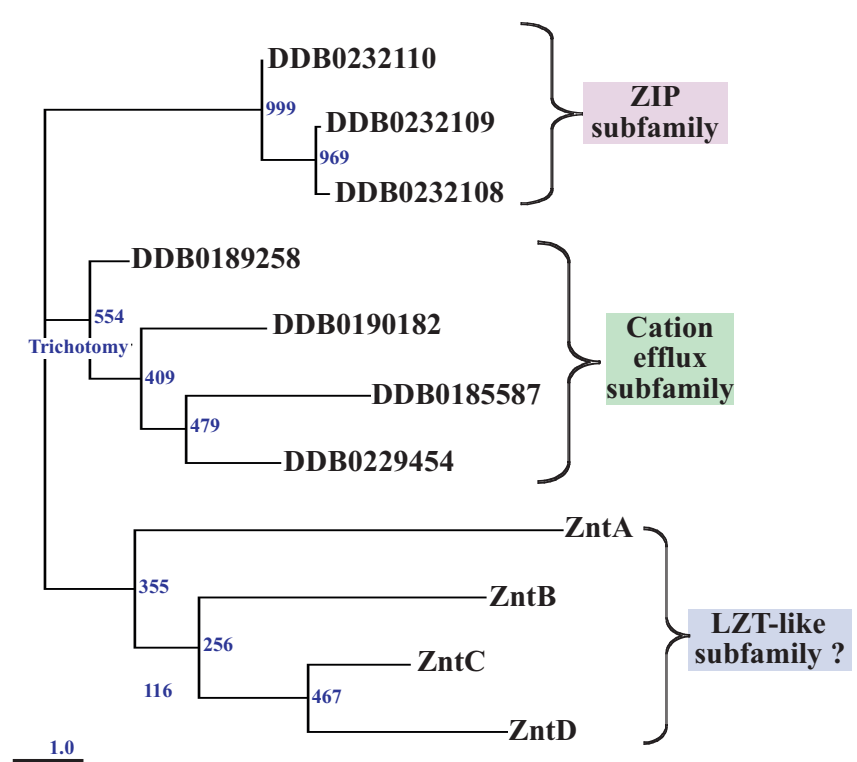

B

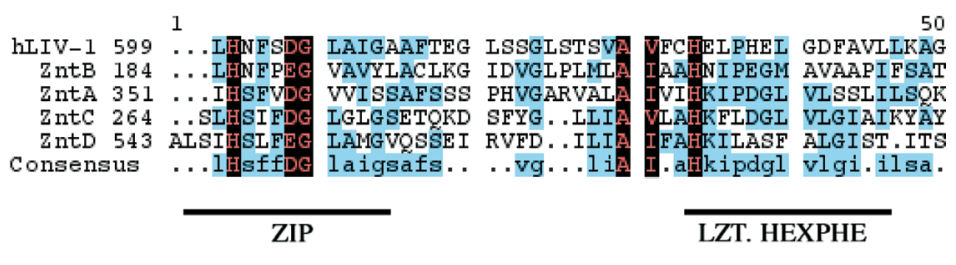

hLIV-1 MTVKOAVLYN A. 656

ZntB GSKWKAFKYC L. 241

ZntA KFNSGIFSNP F. 408

ZntC FSFKFSCIAL VF 321

Consensus SNEKPSFLKL F.

Fig. 1. Putative zinc transporters in Dictyostelium. (A) A phylogenetic tree of zinc transporter family genes in Dictyostelium. The protein names correspond to each protein's primary dictyBase ID or the one designated by the authors, ZntA-D. The phylogenetic tree was created by the TreeView program after ClustalW multiple sequence alignment. Numbers at the branch point indicate the percentage bootstrap support calculated from 1,000 trees. Putative zinc transporters, the ZIP subfamily, the CDF subfamily, and the LZT-like subfamily are indicated. (B) Alignment of Dictyostelium zinc transporter family proteins across putative transmembrane domains IV and $V$. Amino acid sequences of human LIV1 and Dictyostelium ZntA, ZntB, ZntC, and ZntD were aligned by the MultAlin program (Corpet, 1988; $h$ ttp://prodes/toulouse.inra.fe/multalin). Amino acid residues identical among more than $80 \%$ of the family members are shown with pink in black, and residues identical among more than $40 \%$, but less than $80 \%$, of the family members are shaded in pale blue. Positions of amino acid position numbers are shown at both ends. ZIP means the position where is a ZIP conserved sequence (GIVXHSVIIGLSL) in the transmembrane domain IV of ZIP subfamily, while LZT. HEXPHE is the conserved motif of the LZT subfamily in the transmembrane domain V (Taylor and Nicholson, 2003).

genes were classified into three groups (Fig. 1A).

Among the 12 genes, the DDB0232108 (=DDB0217318), $D D B 0232109$ and $D D B 0232110$ genes were predicted to encode ZIP proteins according to their relatively strong homology to Oryza sativaZIP1 (data not shown); thus, they seem to belong to the ZIP subfamily (Fig. 1A). A database search using the amino acid sequence of CDF protein identified four genes, DDB0189258, $D D B 0190182, D D B 0185587$, and DDB0229454. Gene ontology annotations predicted that they encode cation transporters. Thus, they appear to belong to the CDF subfamily (Fig. 1A).

BLAST searches using amino acid sequences derived from LZT proteins identified DDB0202214, DDB0218806,

\section{TABLE 1}

\section{SUMMARY OF ZINC TRANSPORTER FAMILY GENES IN} DICTYOSTELIUM

\begin{tabular}{cccccc}
$\begin{array}{c}\text { Protein Name } \\
\text { (primary dictyBaseID) }\end{array}$ & $\begin{array}{c}\text { EST } \\
\text { clone }\end{array}$ & $\begin{array}{c}\text { Gene } \\
\text { Name }\end{array}$ & Chromosome & $\begin{array}{c}\text { Amino } \\
\text { Acids }\end{array}$ & $\begin{array}{c}\text { Aligned Score } \\
\text { to ZntA }\end{array}$ \\
\hline DDB0232109* & & & $\# 2$ & 375 & 14 \\
DDB0232108 & & & $\# 2$ & 389 & 10 \\
DDB0232110 & & & $\# 3$ & 371 & 14 \\
DDB0218806 & SFB676 & zntB & $\# 4$ & 372 & 12 \\
DDB0186791 & SSK308, & zntC & $\# 4$ & 401 & 20 \\
& dds13d1 & & & & \\
DDB0202214 & SSH647, & \multirow{2}{*}{ zntA } & $\# 1$ & 523 & 100 \\
& dds31e08 & & & & \\
DDB0190179 & & \multirow{2}{*}{ zntD } & $\# 1$ & 683 & 22 \\
DDB0189258 & & & $\# 5$ & 770 & 12 \\
DDB0190182 & & & $\# 1$ & 614 & 11 \\
DDB0185587 & SLC791 & & $\# 4$ & 543 & 16 \\
DDB0229454 & SLF290 & & $\# 3$ & 572 & 8 \\
\hline
\end{tabular}

* There is a duplicated gene (DDB0217318) in strains $A \times 3$ and $A \times 4$ (but not Ax2).
$D D B 0186791$, and $D D B 0190179$ genes. We designated these genes as $z n t A, z n t B, z n t C$, and $z n t D$, respectively. ZntA-D proteins have less similarity to $O$. sativa ZIP1 than supposed Dictyostelium ZIP subfamily proteins have (data not shown). The predicted HEXPHEXGD-like motifs found in their fifth putative transmembrane region (Fig. 1B; Fig. 2, shaded sequences) have very weak homology to the human LIV-1 protein; rather, they show some homologies to ZIP subfamily proteins. However, they still likely belong to a subfamily closer to LZT than to the ZIP or CDF subfamilies. When the amino acid sequences across putative transmembrane domains IV and $\mathrm{V}$ of $\mathrm{ZntA}, \mathrm{B}, \mathrm{C}$, and $\mathrm{D}$ are compared to that of human LIV-1 (Fig. 1B), the first $X$ in the HEXPHEXGD motif is either leucine or isoleucine for the LZT subfamily, while $X$ is phenylalanine for almost all ZIP and CDF subfamilies (Taylor and Nicholson, 2003). Except for ZntC, the others have isoleucine at the same position. The second $X$ is leucine for almost all of the LZT subfamily and is conserved in ZntA and ZntC. In addition, ZntA and ZntB possess a proline

Fig. 2 (Opposite). Predicted amino acid sequences of zinc transporter proteins and hydrophobicities. Predicted amino acid sequences of ZntA-ZntD are shown to the left. Thick lines indicate the putative transmembrane domains (TM I-VII). The sequences with weak homology to the conserved HEXPHEGDFA motif of the LZT subfamily are shaded. Hydrophobicity profiles were created by TMpred (http:// www.ch.embnet.org/software/TMPRED_form.html) with default setting (Hofmann and Stoffel, 1993). Two orientations are possible and both models are shown: one is in-out direction (shown as normal line) and the other is out-in direction (shown as dotted line). Horizontal axis denotes the amino acid number of the predicted protein; the longitudinal axis denotes the hydrophobicity where plus number means hydrophobic. 
ZntA

1 MSIFAYSI LAGLAPLLSSSI PFFTLRNRNINASVFH ILLCI SAGLLFAVASLELIPESMNLALRSEEESTKTQTSLKSTTTT

82 KTTTTTTT IGNIKLQKSEISNSEDSLNEFHSLDNEINKPP IEGLNLNNLNQATNLDNNEE DNDNLDNDGENE IENDHDHDH

163 QEDEGGDNDHDHESEEKKEFLKI PMYGIGS I DGGGGGG GHHS HS HGSLSSSSSNDV ISDY ISNNNSNN INNNDDDNNNNNN

244 NNDDDDDSVELLERNVVNKDNSNNINN INNNNDDEDI IVINKSI ENTPNIAS PVMNKDNNNNDKDKNRNSNKSDIKNSGS I

325 NNGNNSGNNNNNNKSKLTITTFI ALS IHSFVDGVVISSAFSSSPHVGARVALAIVI HKIPDGLVLSSLILSQKKFNSGIFS TMIV TM V

406 NPFFYFLLISCMTPLGSFISSFLFGGLSLSSGAFVLGFGAGTFIYITSTAILPEILSNQI IKFDFKKKNLKKKKKKKKKS TM VI TM VII

487 KPKMEKIDAMGNLKLSSFPFRKE IKKKNQNKNKNKKKR

ZntB

1 MTSLETYNDNVKTALIMCELSGLSTAIGGLYVIFIKQQSHKLLGHLLSFSSGVMIYISFMDLLPES IAEIGFYNANIWFFV TM I TM II TM III

82 GIIFFAVILRFVPHDHDESGDSNHAHSHNGAS IEKHSSEKKEVVDDDDDDNNGKDKKQKQQKQKQQKQQQQQKQNIAKSKN

163 KKKSKDDYLNSVG IATAGVSLHNFPEGVAVYLACLKGI DVGLPLMLAIAAHNIPEGMAVAAPIFSATGSKWKAFKYCLYSG TM IV TM V

244 LCEPVGAIIFGLIFKEYMTPYLIQSMLAAVAGIMVFMV IKELLPAAFKYVSVDESAFSNI IGMIFFFFSIHFLHSMLP HDH TM VI

TM VII

TM VIII

ZntC

1 MDIVNDLVSSISSISSEAAEEEAIRDELRNDKGGLIAGIFVLTLTASFVPWFLTKAKITNLVSVVSILTCLSAGVIIGAGE TM I TM II M II

82 NHILPDAAEEFQSYVEAVAPDNKYGDFPFAHTITIVTMFALICVDKILVSGGLDGEADHNHMDLSQHNHPSPHAAGEIDLN TM III

163 IYTNGDDDDDDVNEDQEEDSTKDDEKEHGHGHGHGHGHNSSNSSSNGHGHGLKKKKKSKKEHGHGHNHDHSSNGHSHKDEK

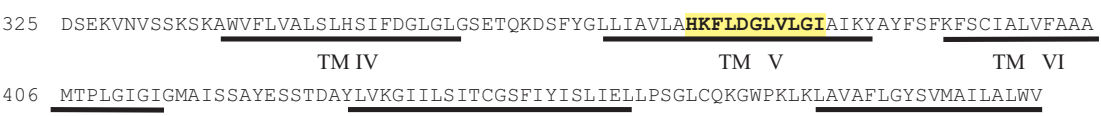

406 MTPLGIGIGMAISSAYESSTDAYLVKGI ILS ITCGSEIYISLIELLPS GLCQKGWPKLKLAVAFLGYSVMAILALWV TM VII

TM VII

ZntD

1 MGISLSVLDIKIISTTVLFILSLLAGIAPYWMRNLNNSSRY LSWSNTFAGGVFFGAGMLHLFATADEDLQPYVQKYNYPEA

82 ALCLCVGFLITLFLELI INSIFIKSNTFASLHGHSHSHVHLSHGHSHHGKDNGSNGNPGSGVGI GMGSVGALNSKKNKTTS TM III

163 PTITPTTPSEGTTTTTTTITATTAATAKEIVLEDEDEDEEKDIMDEI I I DDYDENDDEQIYKKKRQSKCARTKFRKFIDTI

244 PTFSSTSTSSTSSSTKISEKQRLLDSSNSYYYNQNKYKGI IGSHIDIDKSGSGVGGFSNNNNNNNNNNNNNNKNNNNNNNN

325 NFRTEIIIQPISTTSNNSVHHYPSSSVNYHPFITTTTT TCSNDNSNSNNNNSSNNNSSSANI TPNTNKILSSSKSLLSYRYN

406 GDDEE PDI I IDYDDI DYNQEGRTRGNSLGSDSNVHNER IVLINSG I GNSGNIGSNNNNNNNGGGGGGGGNSNIDYNDNEEN

487 NNNNNKIESEILIKDTTTTDS I KNMKGGEHQHQHLHQQE I IVVTKKSNILLPFILVIALS I HSLFEGLAMGVQSSEIRVFDI TM IV

568 LIAIFAHKILASFALGISTITSSNEKPSFLKLFLLVFVFSLTSPIGSILGMVIVGSGVTGSMVPPILQGIASGTFLYVAVV TM $\mathrm{V}$

$\mathrm{TM} \mathrm{VI}$

TM VII

648 EIIPKELSHDSDILIKSELLLLGESGMAVVAIWV

TM VIII
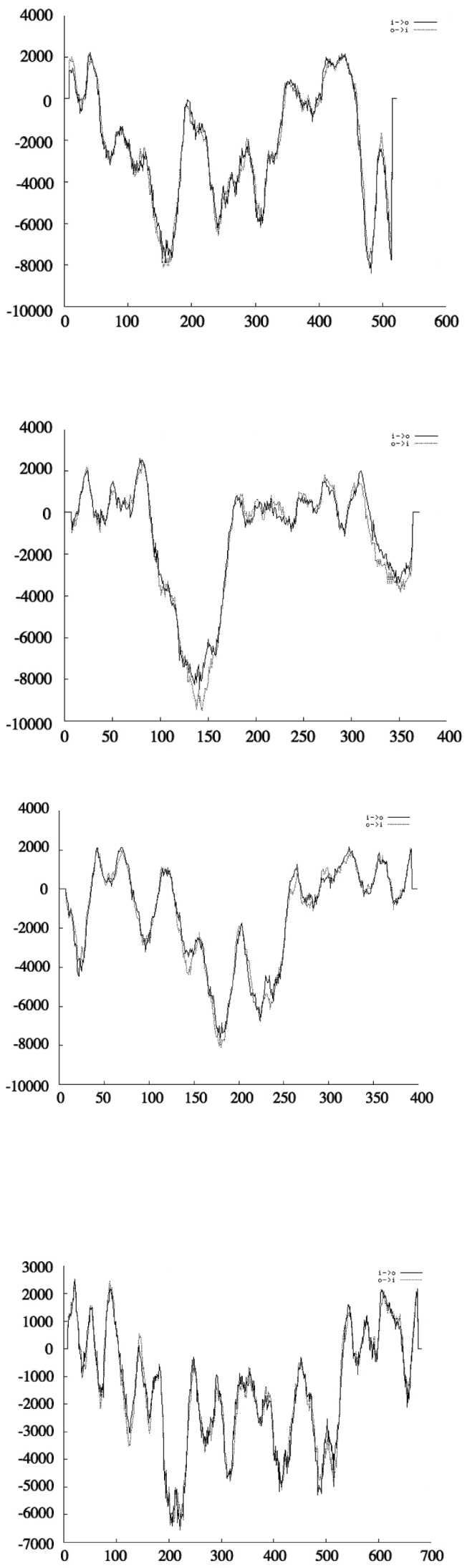
residue that is not found in any ZIP and CDF subfamily proteins. In the transmembrane IV domain, a conserved glycine is next to aspartic acid in LZT, while the glycine is next to isoleucine in most ZIP and CDF subfamily proteins. ZntA-D proteins have acidic residues at the same position (Fig. 1B). This evidence supports the idea that ZntA-D proteins may belong to a subfamily closer to LZT.

To understand the functions of these genes and to clarify whether Dd-STATa regulates their expressions in particular cell types, we compared the expression patterns of $z n t A, z n t B, z n t C$, and $z n t D$ genes in $A \times 2$ and Dd-STATa null strains. In the $A x 2$ strain, all genes were expressed in pstAB cells or at the stalk entrance during culmination (Fig. 3). Both $z n t A$ and $z n t C$ genes were expressed in pstAB cells even in the slug stage. There was almost no cell type-specific expression for these genes in the mutant strain, although there was weak expression in the prestalk cells for the $z n t C$ gene (Fig. 3). These results indicate that Dd-STATa is required for the differentiation of the cell type where zinc transporter family genes are activated. Interestingly, the $z n t D$ gene was expressed in pstAO cells, a cell type that exists even in the Dd-STATanull strain (Mohanty et al., 1999).

The evidence that all four LZT-like zinc transporter family genes are expressed in pstAB cells is important. PstAB cells are strong candidates for "late" organizers during development in Dictyostelium (Sternfeld, 1992; Fukuzawa and Williams, 2000; Shimada et al., 2005). PstAB cells are believed to be the location where stalk elongation begins when culmination is started and may provide a signal or the environment for the initiation of terminal stalk cell differentiation. During culmination, prestalk-to-stalk conversion occurs at the stalk tube entrance to differentiate into pstAB cells (Jermyn et al., 1996). Such a conversion is enhanced by zinc ions in the presence of DIF-1 - at least in the in vitro monolayer cultured cell condition (Kubohara and Okamoto, 1994; Kubohara, 1995). Serafimidis and Kay (2005) suggested that cadmium (and zinc probably) induces polyketide production. Zinc ions might mimic the action of cadmium ions or some zinc transporters might transport cadmium ions which in turn would result in an elevated level of prestalk and stalk differentiation due to a stimulation of polyketide production. Because the $D d$ STATa null strain seems to lack pstAB cells and there is almost no expression of the pstAB-specific genes examined so far in the mutant strain (Shimada et al., 2004b; 2005), zinc concentration may be regulated through expression of zinc transporter genes in pstAB cells by Dd-STATa,
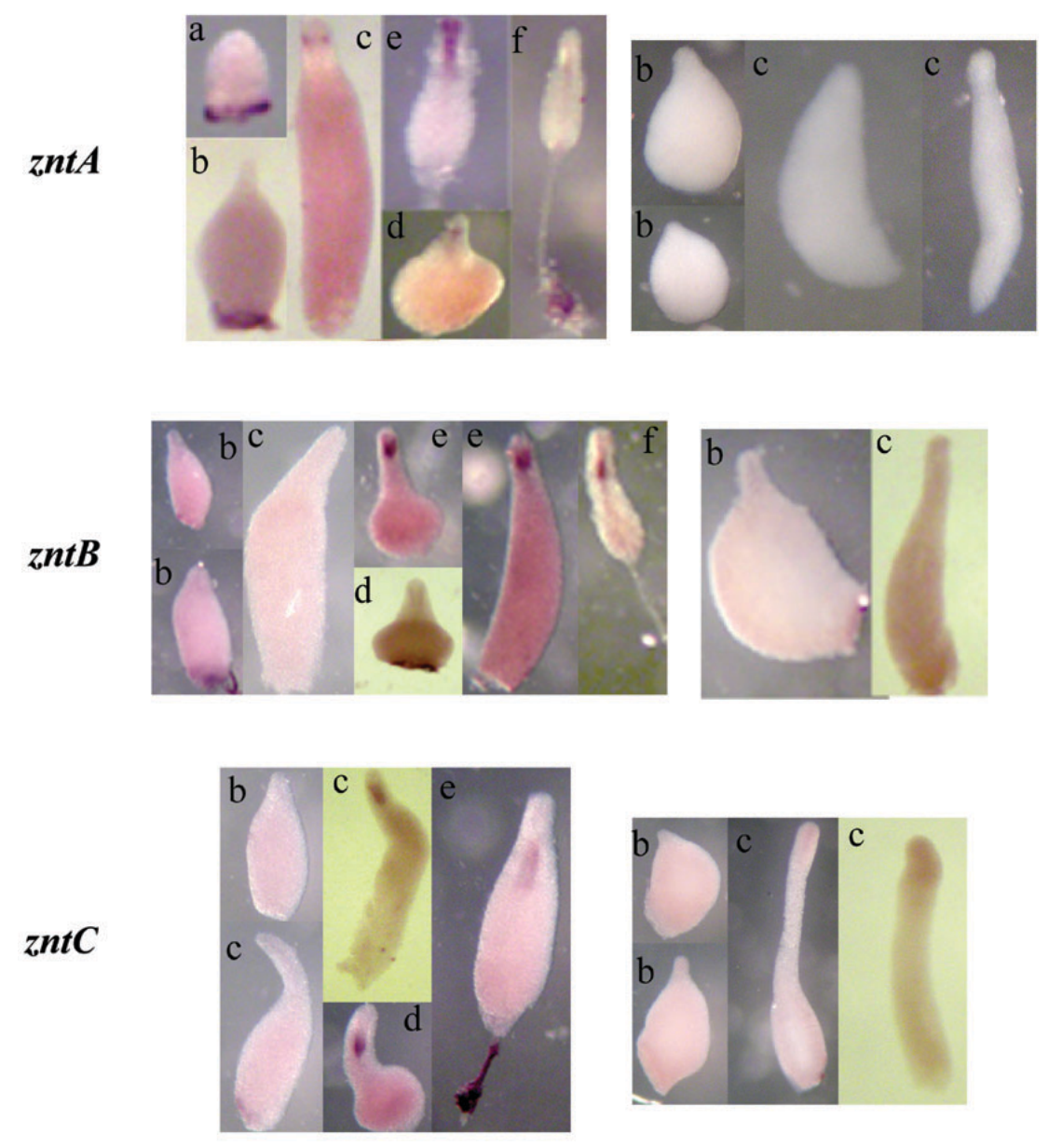

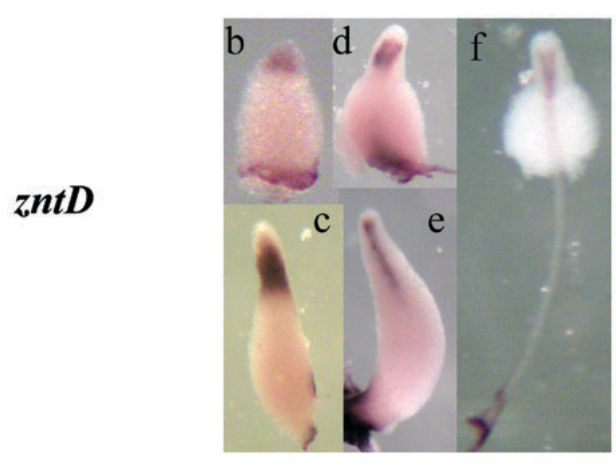

Ax2

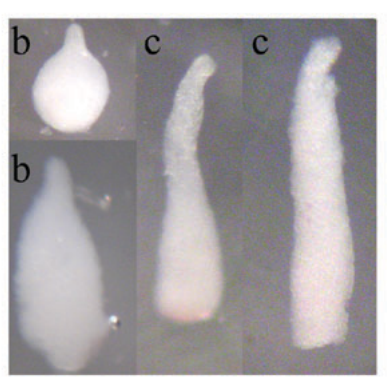

Dd-STATa-null
Fig. 3. Comparison of zinc transporter family gene expression in Ax2 and Dd-STATa null strains. The spatial expression pattern of the zntA-D genes determined by in situ hybridization at the following stages: mound (a), tipped finger (b), slug (c), Mexican hat (d), and culminant $(e, f, g)$ in the Ax2 and Dd-STATa-null strains. The dark regions at the base of multicellular structures from several stages of development in zntA-D are supposed to be non-specific slime sheath staining. The RNA probes were synthesized from EST clone dds31e08 forzntA, SFB676 for zntB, and dds $13 d 1$ for zntC. For zntD, cDNA was amplified, subcloned into pCR-TOPO2.1, and used for probe preparation. The cDNA clones dds31e08 and dds13d1 were provided by Prof. Yuji Kohara, National Institute of Genetics, Japan, as part of the Dictyostelium cDNA project. 
although the mode of action by Dd-STATa may be indirect.

\section{Experimental Procedures}

\section{Cells and growth conditions}

Ax2 and Dd-STATa null strains were grown at $22^{\circ} \mathrm{C}$ in $\mathrm{HL} 5$ medium. Dd-STATa null cells were grown in HL5 medium supplemented with blasticidin S (Kaken Pharmaceutical, Tokyo, Japan).

\section{Identification of genes and phylogenetic analysis}

Amino acid sequences of ZIP, Znt (Zinc Transporter), and LIV1 proteins were obtained from the National Center for Biotechnology Information (NCBI) database (http://www.ncbi.nih.gov/index.html). To identify zinc transporter family genes in Dictyostelium, BLAST searches were performed against the whole genomic sequence of Dictyostelium (Dictybase; http://dictybase.org/) using these amino acid sequences. A phylogenetic tree of identified genes was drawn by the TreeViewPPC program (http://taxonomy.zoology.gla.ac.uk/rod/treeview.html) using sequences aligned by the ClustlalW program (http://www.ddbj.nig.ac.jp/ search/clustalw-j.html).

\section{In situ hybridization}

Whole-mount in situ hybridization was performed as described previously (Escalante and Loomis, 1995; Maeda et al., 2000; 2003; Shimada et al., 2004a).

\section{Acknowledgements}

This work was partly supported by the Science Special Grant for Promoting Scientific Research at Toho University to T. Kawata (301-12) and by a Grant-in-Aid from the Japanese Society for the Promotion of Science (JSTS) Fellowships for Young Scientists to N. Shimada (\#17.2751). N.S. is a JSTS Research Fellow. We thank Prof. YujiKohara, National Institute of Genetics, Japan, for providing the cDNA clones.

\section{References}

BATLLE, E., SANCHO, E., FRANCI, C., DOMINGUEZ, D., MONFAR, M., BAULIDA, J., and GARCÍA DE HERREROS, A. (2000). The transcription factor snail is a repressor of E-cadherin gene expression in epithelial tumour cells. Nat. Cell Biol. 2: 84-89.

CANO, A., PÉREZ-MORENO, M.A., RODRIGO, I., LOCASCIO, A., BLANCO, M.J., DEL, BARRIO, M.G., PORTILLO, F. and NIETO, M.A. (2000). The transcription factor snail controls epithelial-mesenchymal transitions by repressing E-cadherin expression. Nat. Cell Biol. 2: 76-83.

CORPET, F. (1988) Multiple sequence alignment with hierarchical clustering. Nucl. Acids. Res. 16:10881-10890.

DARNELL, J.E., Jr. (1997). STATs and gene regulation. Science 277: 1630-1635.

ESCALANTE, R. and LOOMIS, W.F. (1995). Whole-mount in situ hybridization of cell-type-specific mRNAs in Dictyostelium. Dev. Biol. 43: 262-266.

FUKUZAWA, M. and WILLIAMS, J.G. (2000). Analysis of the promoter of the cudA gene reveals novel mechanisms of Dictyostelium cell type differentiation. Development 127: 2705-2713.

FUKUZAWA, M., ARAKI, T., ADRIAN, I. and WILLIAMS, J.G. (2001). Tyrosine phosphorylation-independent nuclear translocation of a Dictyostelium STAT in response to DIF signaling. Mol. Cel/7: 779-788.

GAO, Q., HUA, J., KIMURA, R., HEADD, J.J., FU, X.Y. and CHIN, Y.E. (2004). Identification of the linker-SH2 domain of STAT as the origin of the $\mathrm{SH} 2$ domain using two-dimensional structural alignment. Mol. Cell. Proteomics 3: 704-714.

GAITHER, L.A. and EIDE, D.J. (2001). Eukaryotic zinc transporters and their regulation. Biometals.14:251-270.

HIROKAWA, T., BOON-CHIENG, S. and MITAKU, S. (1998). Sosui: classification and secondary structure prediction system for membrane proteins. Bioinfomatics 14: 378-379.

HOFMANN, K. and STOFFEL, W. (1993). TMbase - a database of membrane spanning proteins segments. Biol. Chem. Hoppe-Seyler. 347: 166.

JERMYN, K.A., TRAYNOR, D. and WILLIAMS, J.G. (1996). The initiation of basal disc formation in Dictyostelium discoideum is an early event in culmination. Development 122: 753-760.

KAWATA, T., SHEVCHENKO, A., FUKUZAWA, M., JERMYN, K.A., TOTTY, N.F., ZHUKOVSKAYA, N.V., STERLING, A.E., MANN, M. and WILLIAMS, J.G. (1997). SH2 signaling in a lower eukaryote: A STAT protein that regulates stalk cell differentiation in Dictyostelium. Cel/89: 909-916.

KUBOHARA, Y. (1995). Zinc ions promote prestalk-to-stalk and pespore-to-stalk conversions in Dictyostelium discoideum. FEMS Micorobiol. Lett. 134: 15-18.

KUBOHARA, Y. and OKAMOTO, K. (1994). Specific induction by zinc of Dictyostelium stalk cell differentiation. Exp. Cell Res. 214: 367-372.

LIUZZI, J.P., and COUSINS, R.J. (2004). Mammalian zinc transporters. Annu. Rev. Nutr. 24: 151-72.

MAEDA, M., KUWAYAMA, H., YOKOYAMA, M., NISHIO, K., MORIO, T., URUSHIHARA, H., KATHO, M., TANAKA, Y., SAITO, T., OCHIAI, H., TAKEMOTO, K., YASUKAWA, H. and TAKEUCHI, I. (2000). Developmental changes in the spatial expression of genes involved in myosin function in Dictyostelium. Dev. Biol. 43: 114-119.

MAEDA, M., SAKAMOTO, H., MARUO, T., OGIHARA, S., IRANFAR, N., FULLER, D., MORIO, T., URUSHIHARA, H., TANAKA, Y. and LOOMIS, W.F. (2003). Changing patterns of gene expression in Dictyostelium prestalk cell subtypes recognised by in situ hybridisation with genes from microarray analyses. Eukaryot. Cel/2: 638-645.

McCLELLAND, R.A., MANNING, D.L., GEE, J.M., WILLSHER, P., ROBERTSON, J.F., ELLIS, I.O., BLAMEY, R.W. and NICHOLSON, R.I. (1998) Oestrogenregulated genes in breast cancer: association of PLIV1 with response to endocrine therapy. Br. J. Cancer77: 1653-1656.

MOHANTY, S., JERMYN, K.A., EARLY, A., KAWATA, T., AUBRY, L., CECCARELLI, A., SCHAAP, P., WILLIAMS, J.G. and FIRTEL, R.A. (1999). Evidence that the Dictyostelium Dd-STATa protein is a repressor that regulates commitment to stalk cell differentiation and is also required for efficient chemotaxis. Development 126: 3391-3405.

O'SHEA, J.J., GADINA, M. and SCHREIBER, R.D. (2002). Cytokine signaling in 2002: New surprises in the Jak/Stat pathway. Cel/109: S121-S131.

RAWLINGS, J.S., ROSLER, K.M. and HARRISON, D.A. (2004). The JAK/STAT signaling pathway. J. Cell Sci. 117: 1281-1283.

SERAFIMIDIS, I. and KAY, R.R. (2005). New prestalk and prespore inducing signals in Dictyostelium. Dev. Biol. 282: 432-441.

SHIMADA, N., NISHIO, K., MAEDA, M., URUSHIHARA, H. and KAWATA, T. (2004a). Extracellular matrix family proteins that are potential targets of DdSTATa in Dictyostelium discoideum. J. Plant Res. 117:345-353.

SHIMADA, N. MAEDA, M., URUSHIHARA, H. and KAWATA, T. (2004b). Identification of new modes of Dd-STATa regulation of gene expression in Dictyostelium by in situ hybridisation. Int. J. Dev. Biol. 48: 679-682.

SHIMADA, N. MARUO, T., MAEDA, M., URUSHIHARA, H. and KAWATA, T. (2005). Evidence that the Dictyostelium STAT protein Dd-STATa plays a role in the differentiation of inner basal disc cells and identification of a promoter element essential for expression in these cells. Differentiation 73: 50-60.

STERNFELD, J. (1992). A study of PstB cells during Dictyostelium migration and culmination reveals a unidirectional cell type conversion process. Roux's Arch. Dev. Biol. 201: 354-363.

TAYLOR, K.M. and NICHOLSON, R.I. (2003). The LZT proteins; the LIV-1 subfamily of zinc transporters. Biochim. Biophys. Acta. 1611: 16-30.

THUSNÁDY, G.E. and SIMON, I. (1998). Principles governing amino acids composition of integral membrane proteins: application to topology prediction. J. Mol. Biol. 283: 489-506.

YAMASHITA, S., MIYAGI, C., FUKADA, T., KAGARA, N., CHE, Y.S. and HIRANO, T. (2004). Zinc transporter LIVI controls epithelial-mesenchymal transition in zebrafish gastrula organizer. Nature 429: 298-302.

ZHUKOVSKAYA, N.V., FUKUZAWA, M., TSUJIOKA, M., JERMYN, K.A., KAWATA, T., ABE, T., ZVELEBIL, M. and WILLIAMS, J.G. (2004). Dd-STATb, a Dictyostelium STAT protein with a highly aberrant $\mathrm{SH} 2$ domain, functions as a regulator of gene expression during growth and early development. Development 131: 447-458. 


\section{Related, previously published Int. J. Dev. Biol. articles}

See our recent Special Issue Ear Development edited by Fernando Giraldez and Bernd Fritzsch at: http://www.ijdb.ehu.es/web/contents.php?vol=51\&issue=6-7

See our Special Issue Mammalian Reproduction \& Development in honor of Anne McLaren and edited by Brigid Hogan at: http://www.ijdb.ehu.es/web/contents.php?vol=45\&issue=3

Analysis of a homologue of the adducin head gene which is a potential target for the Dictyostelium STAT protein Dd-STATa

Ryota Aoshima, Rieko Hiraoka, Nao Shimada and Takefumi Kawata

Int. J. Dev. Biol. (2006) 50: 523-532

Identification of new modes of Dd-STATa regulation of gene expression in Dictyostelium by in situ hybridisation

NAO SHIMADA, MINEKO MAEDA, HIDEKO URUSHIHARAand TAKEFUMI KAWATA

Int. J. Dev. Biol. (2004) 48: 679-682

Expression and role of adenylyl cyclases during late development in Dictyostelium discoideum E Alvarez-Curto, ME Meima, P Schaap

Int. J. Dev. Biol. (2001) 45: S147-S148

The MADS-box transcription factor SRFA regulates different aspects of Dictyostelium discoideum development

N Moreno, JJ Vicente, R Escalante, L Sastre

Int. J. Dev. Biol. (2001) 45: S117-S118

Cell cycle phase, cellular $\mathrm{Ca} 2+$ and development in Dictyostelium discoideum.

M Azhar, P K Kennady, G Pande, M Espiritu, W Holloman, D Brazill, R H Gomer and V Nanjundiah

Int. J. Dev. Biol. (2001) 45: 405-414

Dictyostelium discoideum: a model system for differentiation and patterning.

$\mathrm{R}$ Escalante and $\mathrm{J} \mathrm{J}$ Vicente

Int. J. Dev. Biol. (2000) 44: 819-835

Cell-cell signaling and adhesion in phagocytosis and early development of Dictyostelium.

E Bracco, B Pergolizzi, B Peracino, E Ponte, A Balbo, A Mai, A Ceccarelli and $S$ Bozzaro

Int. J. Dev. Biol. (2000) 44: 733-742

A cell type-specific effect of calcium on pattern formation and differentiation in dictyostelium discoideum.

R Baskar, P Chhabra, P Mascarenhas and V Nanjundiah

Int. J. Dev. Biol. (2000) 44: 491-498

2006 ISI ${ }^{* *}$ Impact Factor $=3.577^{* *}$

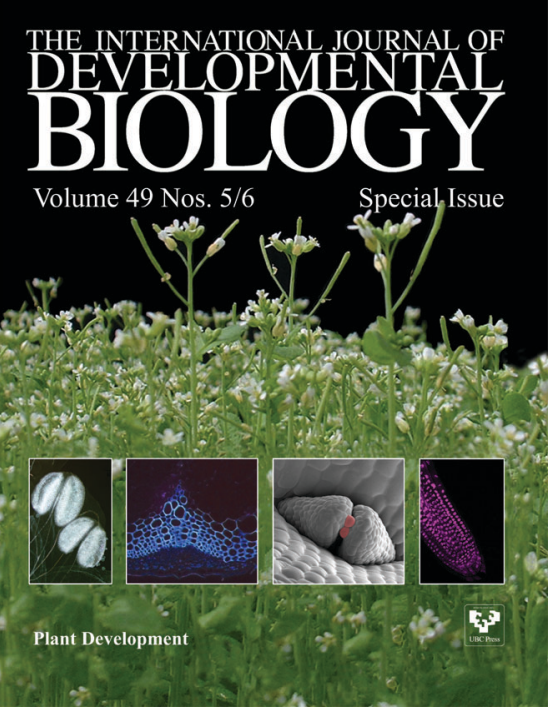

